\title{
Assessment of Impacts of Climate Change and Adaptation Measures for Maize Production in East Sikkim, India
}

\author{
Proloy Deb* \& S. Babel \\ Water Engineering and Management, Asian Institute of Technology, P.O. Box 4, Klong Luang, \\ Pathumthani, 12120, Thailand
}

\begin{abstract}
An investigation was carried out to assess the impacts of climate change on rainfed maize yield using a yield response to water stress model (AquaCrop) and to identify suitable adaptation options to minimize the negative impacts on maize yield in East Sikkim, North East India. Crop management and yield data was collected from the field experimental plots for calibration and validation of the model for the study area. The future climate data was developed for two IPCC emission scenarios A2 and B2 based on the global climate model HadCM3 with downscaling of climate to finer spatial resolution using the statistical downscaling model, SDSM. The impact study revealed that there is an expected reduction in maize yield of 12.8, 28.3 and $33.9 \%$ for the A2 scenario and 7.5, 19.9 and 29.9\% for the B2 scenario during 2012-40, 2041-70 and 207199 respectively compared to the average yield simulated during the period of 1961-1990 with observed climate data. The maize yield of same variety under future climate can be maintained or improved from current level by changing planting dates, providing supplement irrigation and managing optimum nutrient.
\end{abstract}

Keywords: Climate change, Crop modeling, agro-adaptation, North East India, IPCC scenarios

\section{INTRODUCTION}

Climate change is expected to have wide-ranging serious threat to socio-economic and environmental sectors specifically to water and agricultural sectors (IPCC, 2007; Molua, 2009). Food production is expected to enter in a nonsustainable cycle with increasing population along with climate change as the main driving forces (Horie, 2005). Agricultural production is substantially affected by the various climate ex- treme events like droughts, floods, cyclones and heat waves (Alcamo et al., 2007).

Declining crop yield trend has already been noticed in most Asian countries due to significant shift in precipitation pattern and changed temperature (IPCC, 2007). Several studies have further shown that the decrease in yield of many crops in developing countries is expected in the future due to climate change (Babel et al., 2011; Nelson et al., 2009). Increased temperature al-

* Corresponding author : Proloy Deb, E-mail: debproloy@gmail.com 
ters the growing period of crops, potential photosynthesis ability and changes the water and nutrient budgets (Long, 1991). From a plant philosophy point, an increase in $\mathrm{CO}_{2}$ can be beneficial to the photosynthesis resulting higher yield (Kimball, 1983). Long (1991) showed changes in temperature and precipitation may also affect crop photosynthesis ultimately affecting the plant growth rate and yield. However, the effect of climate change on agriculture depends on the location; places where temperature affects the length of growing season, warmer conditions are beneficial. On contrary, places with warm springs and summer can be badly affected. Rainfed agriculture is dominant in developing countries which are vulnerable to climate change due to the alteration of temperature and the precipitation patterns.

Mountain and hill agriculture contribute a substantial proportion of the world's agricultural production in terms of economic value (Meybeck et al., 2001). Upland agricultural production, which is practiced close to margins of viable production, can be highly sensitive to variations in climate. However, the nature of sensitivity varies according to the region, crop and agricultural system of interest. Several regional studies have been conducted on climate change impacts on agriculture at various regions of world (Rui-Li and Geng, 2013; Wang et al., 2013; Babel et al., 2011; Meza et al., 2008; Tao et al., 2006; Reilly et al., 2003). All these studies were performed at plain and valley since density of population in these regions are more compared to mountain tracks. Only a handful of studies were done at higher altitudes (Gao et al., 1993; Li et al., 1993; Ma and Liang, 1990) which indicates higher temperature would benefit the agricultural production. However, study conducted by Carter and Parry (1994) shows higher temperature during the reproductive phase in maize will reduce the productivity in higher hills of Japan.

Adaptation strategies related to management practices serve as an alternative to reduce the negative impacts of climate change (Rivington et al., 2013; Meza et al., 2008). Evaluation of adaptation strategies in agriculture has become the prime focus of research for plain regions leaving the mountainous agriculture in threat. The major aim of this research is to assess the negative impacts of climate change in mountain maize production and to evaluate various agroadaptation practices for sustainable maize production.

\section{STUDY AREA}

The present study was conducted in the East Sikkim district of the Sikkim state which is landlocked by Bhutan in the east and other state and districts on two sides. Geographically it lies between $27^{\circ} 08^{\prime}$ and $27^{\circ} 26^{\prime} \mathrm{N}$ latitudes and $88^{\circ} 27^{\prime}$ and $88^{\circ} 54^{\prime} \mathrm{E}$ longitudes (Figure 1). The altitude in the study area varies from $270-4636$ $\mathrm{m}$. The climate is moderately sub-tropical with an average annual rainfall (AAR) of $3300 \mathrm{~mm}$ and $80 \%$ occurring in the monsoon season (June to September), the rest of the year mostly dry. The mean annual maximum and minimum temperatures are 23.5 and $13.9^{\circ} \mathrm{C}$ respectively. The average temperature decreases with altitude, although it also varies spatially with topography.

Undulating slopes and rocky terrain are dominant in the region which makes it unfit for lowland agricultural practices. However, agricultural practices are performed by converting the hills to farm lands by using terraces. Due to high acidity of the soil crops which are sensitive to acid are not preferred. The physico-chemical properties vary with altitude and depth of soil 


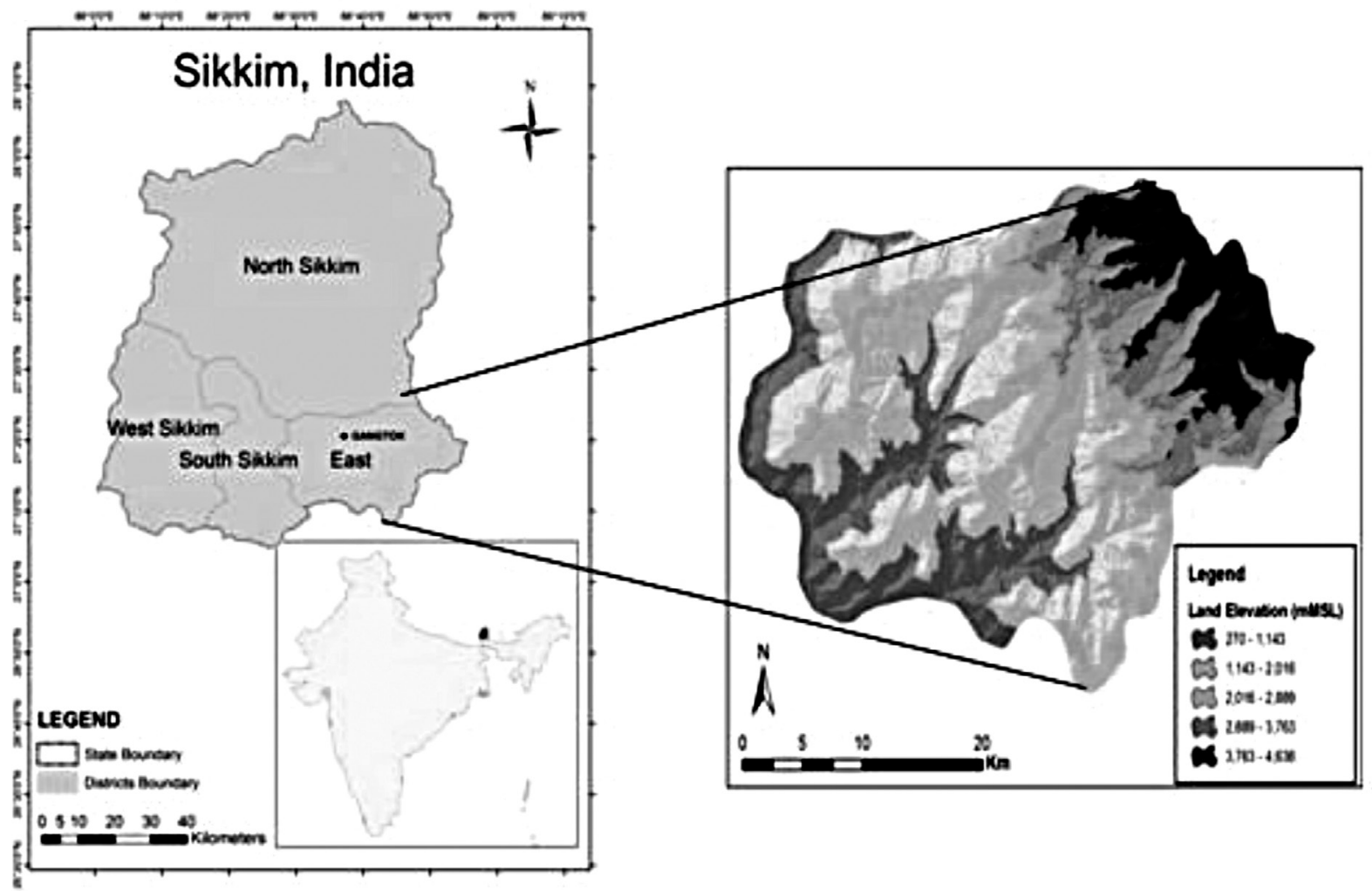

Figure 1 : The location of the study area along with digital elevation model

Table 1 Physical and chemical properties of soil according to depth

\begin{tabular}{ccccc}
\hline Determination & \multicolumn{4}{c}{ Soil depth $(\mathrm{cm})$} \\
\cline { 2 - 5 } & $0-20$ & $21-60$ & $61-76$ & $77-120$ \\
\hline Sand (\%) & 23 & 29 & 23 & 25 \\
Silt (\%) & 63 & 27 & 23 & 28 \\
Clay $(\%)$ & 14 & 44 & 54 & 47 \\
Soil texture & Silty clay & Clay & Clay & Clay \\
FC (\% vol) & 50 & 55 & 53 & 54 \\
PWP (\% vol) & 32 & 37.7 & 40 & 38.5 \\
K (mm/day) & 15 & 2 & 2.4 & 3 \\
Bd (g cm $\left.{ }^{-3}\right)$ & 1.36 & 1.24 & 1.22 & 1.09 \\
CEC (emol kg & 10.4 & 23.7 & 22.3 & 20.2 \\
pH & 5 & 3.7 & 4 & 4.7 \\
OC (g kg $\left.{ }^{-1}\right)$ & 20 & 15 & 3 & 0 \\
N (ppm) & 172 & 155 & 142 & 118 \\
P (ppm) & 3.3 & 3.6 & 4.5 & 4.2 \\
K (ppm) & 166 & 174 & 156 & 180 \\
\hline
\end{tabular}

(Source: Debnath et al., 2012) 
(Debnath et al., 2012). Table 1 illustrates the average properties of the soil in the root zone in the study area.

\section{MATERIALS AND METHODS}

The present study is based on secondary data collected from the agricultural and meteorological research stations. Meteorological data collected includes daily observations of maximum and minimum temperatures, precipitation, average humidity, sunshine hours and wind speed recorded from 1980 up to 2011. Future climate data is retrieved for the most pessimistic and optimistic IPCC scenarios A2 and B2 respectively from the global circulation model (GCM) Hadley Centre Coupled Model version 3 (HadCM3) by Met office Hadley Centre, England. Statistical downscaling tool (SDSM v4.2) has been used to downscale the coarse resolution of the climate variables obtained from GCM to basin scale which is further

used for the impact assessment and evaluate adaptation. Field experiments with several combinations of irrigation and farm yard manure (FYM) application were done for NLD-White hybrid variety of maize for the year 1998, 2002, 2004, 2005, 2009 and 2010. Dataset of first four years is used to calibrate and the remaining two is used to perform validation of the crop model AquaCrop v3.1. The calibrated model has been used to forecast the future Maize yield under projected climate variables. Evaluations of the most suitable agro-adaptation measures are done to minimize the negative impacts of climate change.

\subsection{Downscaling climate variables}

GCMs predict the climate variables at a global level which is not suitable for basin scale stud- ies, and moreover the regional features of local level are not amalgamated in GCMs (Russo and Jack, 1997). Downscaling is the process of transforming the GCM outputs to local level (IPCC, 2007). Although, there are several methods of downscaling the coarse resolution data of GCMs to basin level viz., dynamical method, weather typing, stochastic weather generators and regression, the statistical downscaling method is preferred due to its cost effectiveness and its easiness to perform rapid assessments of localized climate (Bardosy and Plate, 1992). Statistical DownScaling Model (SDSM) has become more accepted in recent years due to its applicability in wide region and simplicity of establishing relationship between predictor and predictand variables for future time zone (Wilby et al., 2002). Hence, SDSM package of decision support tool is used for this study to downscale maximum, minimum temperature and precipitation for the study area for (2012-2040) 2025s, (2041-2070) 2055s and (2071-2099) 2080's. Prior to forecasting the future climate variables, SDSM has been calibrated based on observed data of 1961-90 and then validated for the period of 1991-2000.

\subsection{AquaCrop v 3.1}

The model relates soil-water-atmosphere components through its soil and water balance, atmosphere (rainfall, temperature, carbon dioxide $\left(\mathrm{CO}_{2}\right)$ composition and evapotranspiration), crop conditions (crop cover, phenology) and field management (Irrigation, agronomic practices) components (Raes et al., 2009; Steduto et al., 2009). Daily water balance is calculated in AquaCrop and evapotranspiration is divided into evaporation and transpiration. The water productivity is an important parameter which is normalized based on three correction fac- 


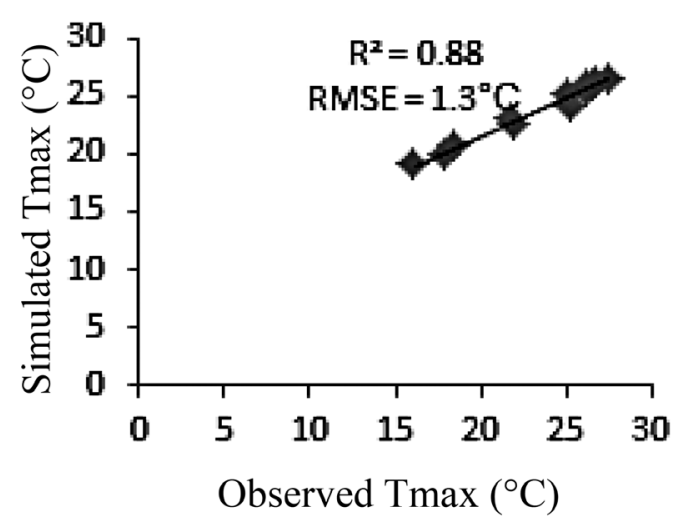

(a)

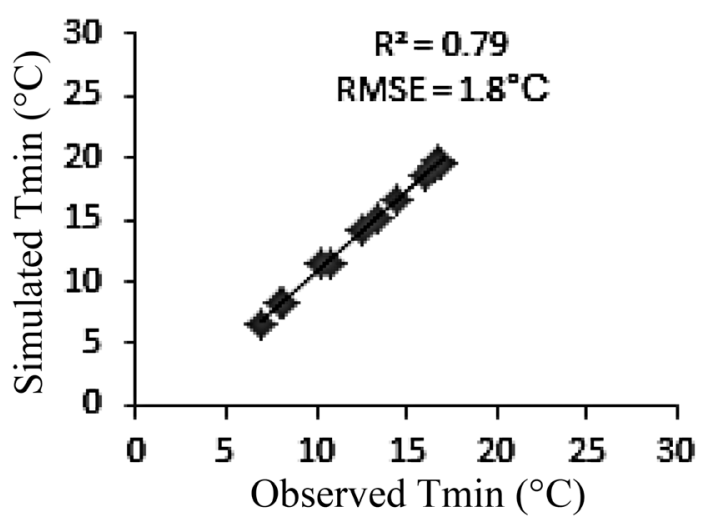

(b)

Figure 2 : Comparison of observed and simulated monthly (a) maximum and (b) minimum temperature averaged for 19912000 for East Sikkim using SDSM.

tors $\left(\mathrm{CO}_{2}\right.$, air temperature and water). Based on normalized crop water productivity, AquaCrop calculates daily aboveground biomass production (Hsiao et al., 2009). Yield is calculated as a product of biomass and harvest index (HI). HI is further adjusted for five water stress coefficients namely coefficient for inhibition of leaf growth, for inhibition of stomata, reduction in green canopy duration due to senescence, reduction in biomass due to pre-anthesis stress and for pollination failure (Raes et al., 2009). HI was set between $30-40$ percent for maize as per recommendations.

\subsection{Criteria for model evaluation}

AquaCrop has been calibrated using measured data of four years and validation has been performed based on dataset of two years. The robustness of the model during the calibration and validation process is evaluated by coefficient of determination $\left(\mathrm{R}^{2}\right)$, Root Mean Square Error (RMSE) and Mean Bias Error (MBE). $\mathrm{R}^{2}$ value closer to 1 indicates better performance, however lower value tending to 0 for RMSE and MBE indicates model is in good agreement with observed data.

\section{RESULTS AND DISCUSSTION}

\subsection{Observed and simulated climate data}

The mean monthly maximum, minimum temperature and precipitation averaged for the base period of 1991-2000 has been used to check the consistency of the simulated data. The observed mean maximum temperature (Tmax) for the base period is $23.3 \pm 3.7^{\circ} \mathrm{C}$ whereas the modeled mean maximum temperature is 23.6 $\pm 2.5^{\circ} \mathrm{C}$. In case of mean minimum temperature (Tmin), the observed and simulated temperatures are $12.5 \pm 1.2{ }^{\circ} \mathrm{C}$ and $14.1 \pm 0.7^{\circ} \mathrm{C}$ respectively. The corresponding coefficient of determination for Tmax and Tmin are 0.88 and 0.79 respectively whereas the RMSE are $1.3^{\circ} \mathrm{C}$ and $1.8^{\circ} \mathrm{C}$ respectively. The monthly weather pattern for the Tmax and Tmin for the 10 years interval as shown in the Figure 2 shows a good agreement among the observed and simulated values.

Observed and simulated average annual precipitation for the station for a period of 1961 - 1991 are $3282 \pm 220 \mathrm{~mm}$ and $3707 \pm 251$ $\mathrm{mm}$ respectively. The coefficient of determination and RMSE for the observed and simulated precipitation is in order of 0.87 and 98.56 


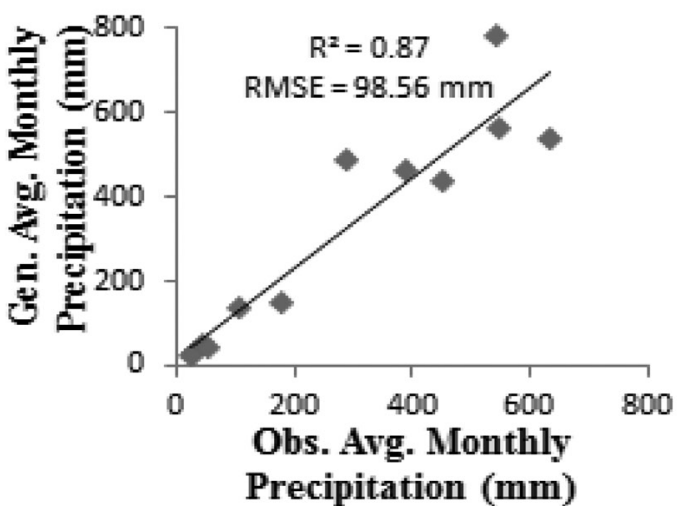

(a)

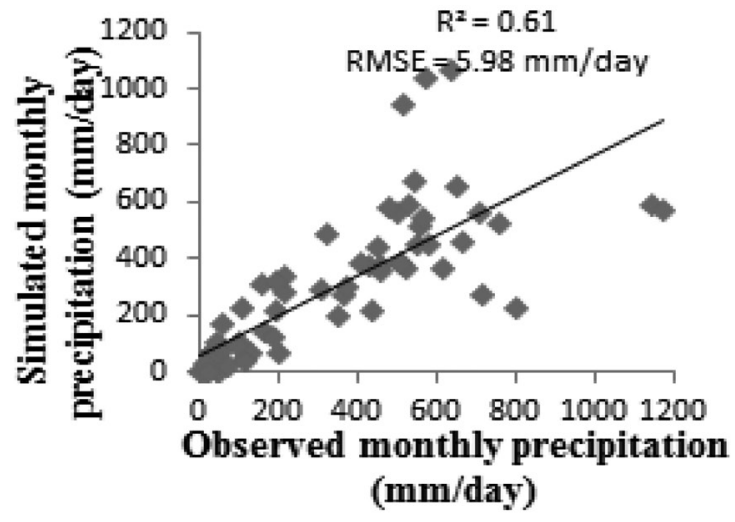

(b)

Figure 3 : Validation results for downscaling using SDSM for (a) average monthly and (b) monthly precipitation for 1991 2000.

Table 2 Average relative change in the climatic parameters compared to baseline period of 1961-90

\begin{tabular}{|c|c|c|c|c|c|c|c|c|}
\hline \multirow[b]{2}{*}{$\begin{array}{l}\text { Time } \\
\text { Period }\end{array}$} & \multicolumn{4}{|c|}{ A2 scenario } & \multicolumn{4}{|c|}{ B2 scenario } \\
\hline & $\begin{array}{c}\mathrm{CO}_{2} \\
\text { conc. } \\
\text { (ppm) }\end{array}$ & $\begin{array}{l}\text { Tmax } \\
\left({ }^{\circ} \mathrm{C}\right)\end{array}$ & $\begin{array}{l}\text { Tmin } \\
\left({ }^{\circ} \mathrm{C}\right)\end{array}$ & $\begin{array}{l}\text { Prcp. } \\
\text { (mm) }\end{array}$ & $\begin{array}{c}\mathrm{CO}_{2} \\
\text { conc. } \\
\text { (ppm) }\end{array}$ & $\begin{array}{l}\text { Tmax } \\
\left({ }^{\circ} \mathrm{C}\right)\end{array}$ & $\begin{array}{l}\text { Tmin } \\
\left({ }^{\circ} \mathrm{C}\right)\end{array}$ & $\begin{array}{l}\text { Prcp. } \\
\text { (mm) }\end{array}$ \\
\hline $\begin{array}{l}\text { 1961- } \\
1990 *\end{array}$ & 330 & 23.5 & 13.9 & 3345 & 330 & 23.5 & 13.9 & 3345 \\
\hline $\begin{array}{l}2012- \\
2040\end{array}$ & 88.80 & 0.4 & 0.4 & -220 & 76.96 & 0.4 & 0.4 & -342 \\
\hline $\begin{array}{l}2041 \text { - } \\
2070\end{array}$ & 199.72 & 0.8 & 0.9 & -273 & 147.25 & 0.7 & 0.8 & -336 \\
\hline $\begin{array}{l}2071- \\
2099\end{array}$ & 374.95 & 1.4 & 1.6 & -540 & 227.44 & 1.0 & 1.1 & -421 \\
\hline
\end{tabular}

considered the absolute observed values for both the scenarios

mm respectively. Figure 3 (a) and (b) shows the comparison of the observed and simulated monthly average and monthly precipitation for 1991-2000. The statistical evaluation suggests the simulated precipitation is in good agreement with the observed.

\subsection{Projected climate}

The relative changes in the carbon dioxide concentration, maximum, minimum temperature and precipitation for the study area projected for A2 and B2 scenarios for periods of 20122040, 2041-2070, and 2071-2099 as relative to the baseline period of $1961-1990$ is provided in the Table 2 .

In case of Tmax, the average annual maximum temperature for the base period (1961-90) is $23.7 \pm 2.7^{\circ} \mathrm{C}$ which increases to $24.1 \pm 2.7^{\circ} \mathrm{C}$, $24.5 \pm 2.7^{\circ} \mathrm{C}$ and $25.1 \pm 2.8^{\circ} \mathrm{C}$ for $2012-2040$, 2041-2070 and 2071-2099 respectively for A2 scenario. In case of B2 scenario the temperature is expected to increase $24.1 \pm 2.8^{\circ} \mathrm{C}, 24.4$ $\pm 2.7^{\circ} \mathrm{C}$ and $24.7 \pm 2.8^{\circ} \mathrm{C}$ for $2012-2040$, 


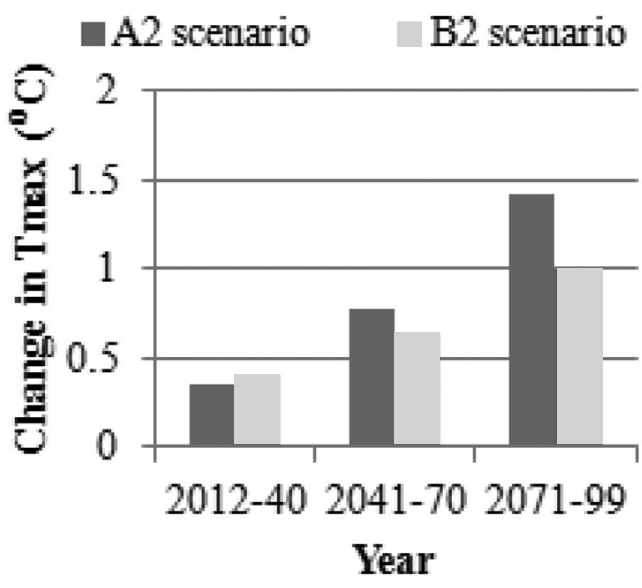

(a)

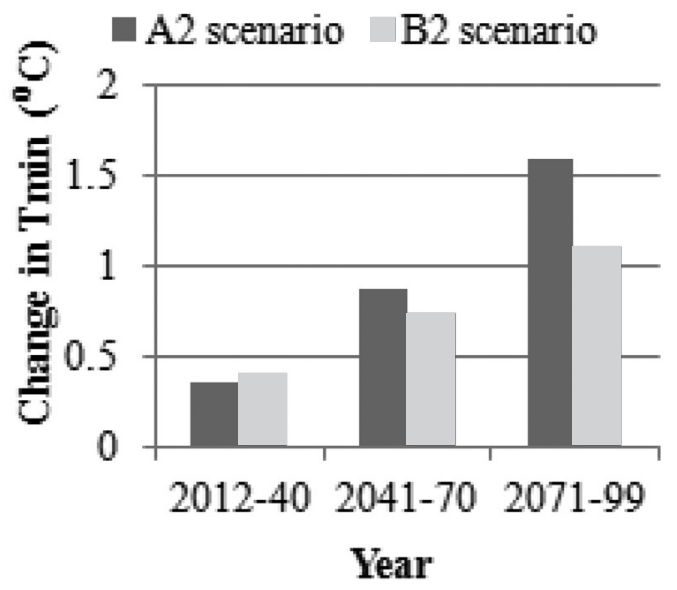

(b)

Figure 4 : Projected change in the average annual (a) maximum and (b) minimum temperature in East Sikkim relative to $1961-90$.

$2041-2070$ and $2071-2099$ respectively. For the case of Tmin, the average annual minimum temperature for A2 scenario, the base period temperature is $12.8 \pm 2.2^{\circ} \mathrm{C}$ which is probable to increase upto $13.2 \pm 4.9^{\circ} \mathrm{C}, 13.7 \pm 2.2^{\circ} \mathrm{C}$ and $14.4 \pm 2.2{ }^{\circ} \mathrm{C}$ for $2012-2040,2041-2070$ and 2071-2099 respectively. For B2 scenario the simulated temperature increases to $13.2 \pm 2.2$ ${ }^{\circ} \mathrm{C}, 13.6 \pm 2.2{ }^{\circ} \mathrm{C}$ and $13.9 \pm 2.3{ }^{\circ} \mathrm{C}$ for $2012-$ 2040, 2041-2070 and 2071-2099 respectively. The average change in annual temperature and monthly variation in maximum and minimum for SRES A2 and B2 scenarios are presented in Figure 4 (a) and (b).

Analysis on precipitation shows that there has been a substantial decreasing trend in the forecasted precipitation. The analysis shows that in case of A2 scenario, the average annual precipitation will decrease from the baseline period of $3700 \mathrm{~mm}$ to $3480 \mathrm{~mm}, 3427 \mathrm{~mm}$ and $3160 \mathrm{~mm}$ from baseline period of 1960-90 to 2012-2040, 2041-2070 and 2071-2099. Similarly, in case of B2 scenario the average annual precipitation the decreasing trend progresses to higher magnitude from $3700 \mathrm{~mm}$ to $3358 \mathrm{~mm}, 3364$ $\mathrm{mm}$ and $3279 \mathrm{~mm}$ for 2012-2040, 2041-2070 and 2071-2099 respectively. It is clear from the analysis that the drier season (winter) will get drier with time for both the scenarios. Only in case of 2041-2070 in A2 scenario the precipitation increases in the monsoon season. The maximum reduction in the average monthly precipitation from the baseline period is for B2 scenario November with a decrease of $87 \%$ whereas in case of A2 scenario the decrease is $72 \%$. The maximum rainfall has been observed in September with an amount of almost 800 $\mathrm{mm}$ which is almost constant for all the time slides for both the scenarios whereas the minimum rainfall is observed in December with an amount of $23 \mathrm{~mm}$ for all the time slices and both the scenarios.

\subsection{Calibration and validation of the model}

The observed and simulated yield components at the study site as presented in Table 3 indicates the model results are in good agreement with the observed data. MBE indicates that during both calibration and validation process, the 
Table 3 Model performance during calibration and validation process

\begin{tabular}{lcccccc}
\hline Variables & \multicolumn{3}{c}{ Calibration } & \multicolumn{3}{c}{ Validation } \\
\cline { 2 - 6 } & $\mathrm{R}^{2}$ & RMSE & MBE & $\mathrm{R}^{2}$ & RMSE & MBE \\
\hline Yield (t/ha) & 0.84 & 0.23 & -0.11 & 0.89 & 0.46 & -0.04 \\
$\begin{array}{l}\text { Biomass } \\
\text { (t/ha) }\end{array}$ & 0.87 & 0.38 & -0.21 & 0.87 & 0.74 & 0.18 \\
$\begin{array}{l}\text { WP } \\
\text { (kg/ha.mm) }\end{array}$ & 0.88 & 0.26 & -0.04 & 0.97 & 0.59 & -0.43 \\
\hline
\end{tabular}

model underestimates all the output variables except for biomass in validation which is +0.18 $\mathrm{t} / \mathrm{ha}$. Lower RMSE is observed in case of calibration process due to higher care during the process of parameterization of the model. Minimal error exists in the parameterization process due to model and human errors.

\subsection{Projected maize yield under climate change}

This study shows there will be a significant decrease in the yield simulated by the crop model for the two emission scenarios A2 and B2 considered. The yield simulated by AquaCrop shows a decline of $12.8 \%, 28.3 \%, 33.9 \%$ and $7.5 \%, 19.9 \%, 29.9 \%$ for $2012-40,2041-70$ and
2071-99 as compared to the yield of the baseline period for A2 and B2 emission scenarios respectively. Figure 5 shows the average percent change in the yield for the three time slices 2012-40, 2041-70 and 2071-99 using the crop model for the two scenarios. Table 4 shows the decadal percent reduction in the yield simulation using the model for both the emission scenarios. The decadal analysis of the reduced yield shows that, for the simulation done for A2 scenario by AquaCrop, the decadal yield reduction increases from $4.28 \%$ in $2012-40$ to $5.89 \%$ in $2041-70$ and reduces again to $2.60 \%$ by 2071-99. Similarly in case of B2 scenario, the decadal yield reduction increases from $2.49 \%$ in $2012-40$ to $4.46 \%$ in $2041-70$ and then again reduces to $4.17 \%$ in $2070-99$.

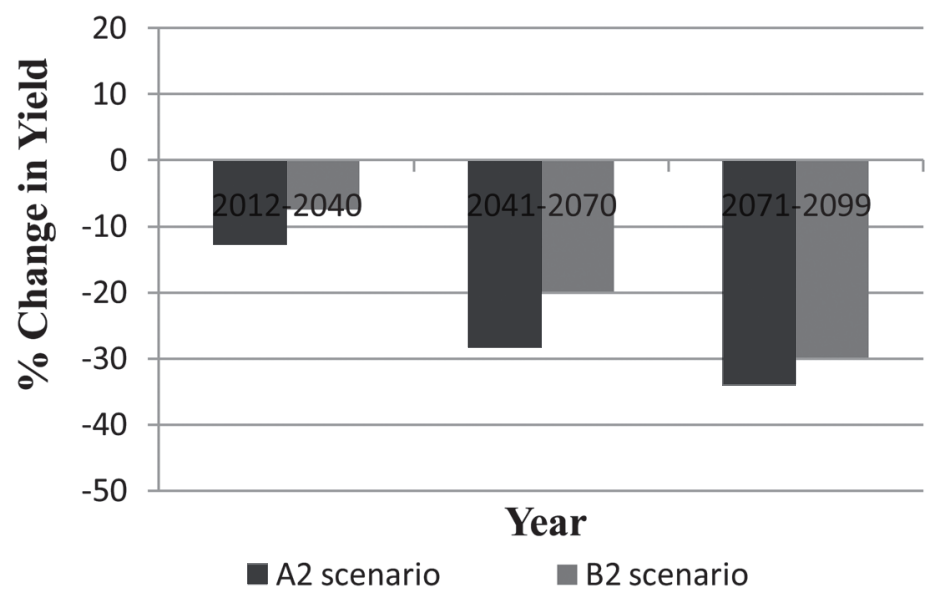

Figure 5 : Percentage change in maize yields for A2 and B2 SRES scenarios for the period of 2012-40, 2041-70 and 2071-99 relative to $1961-90$ average yield simulated by AquaCrop. 
Table 4 Percent reduction in yield simulation on a decadal basis using the crop model

\begin{tabular}{lccc}
\hline Scenarios & \multicolumn{3}{c}{ \% reduction /decade } \\
\cline { 2 - 4 } & $2012-2040$ & $2041-2070$ & $2071-2099$ \\
\hline AquaCrop & 4.28 & 5.89 & 2.60 \\
A2 & 2.49 & 4.46 & 4.18 \\
B2 & & & \\
\hline
\end{tabular}

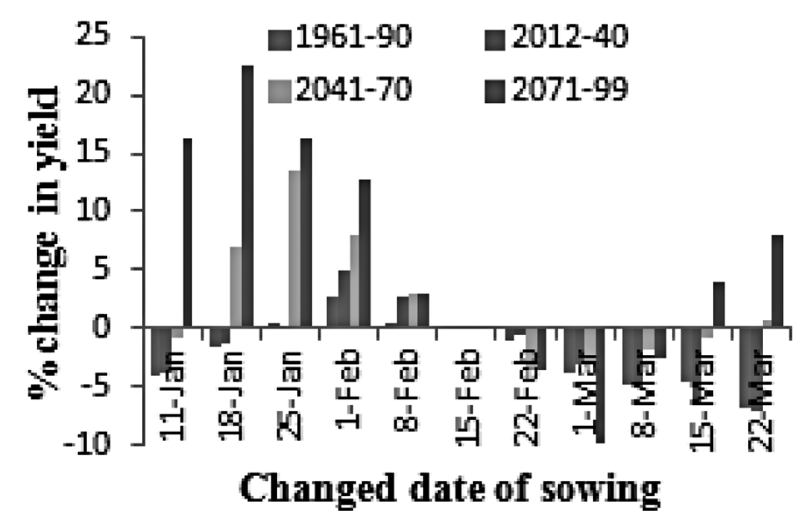

(a)

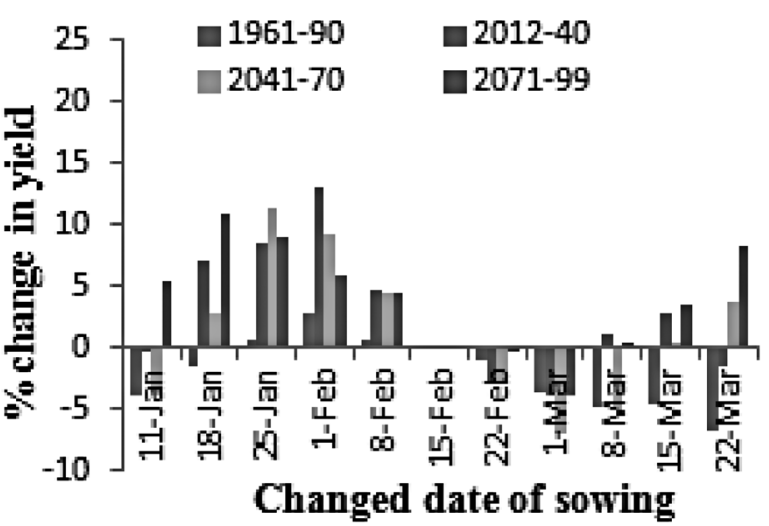

(b)

Figure 6 : Percent change in yield with different sowing dates for NLD - White (a) A2 scenario and (b) B2 scenario.

Supit et al. (2012) determined there is an expected reduced yield trends in the future in most of the parts of Europe except the northern polar zones where the yield seems to follow an increasing one for A2 and B1 SRES. Tao and Zhao (2010) predicted a change of $-13.2 \%$ to $-19.1 \%$ in 2050 's, relative to $1961-1990$ in the entire China using super-ensemble-based probabilistic projection system (SuperEPPS). Meza et al. (2008) forecasted reduction of 10\% to $30 \%$ based on different scenarios and varieties used in entire Chile.

Various agro-adaptation measures to reduce the severe effect of the climate change on agriculture have been evaluated by many researchers. The measures on which evaluation has been done in this research are introducing supplementary irrigation, changing sowing date and changing the input of nitrogen (FYM).

\subsection{Effect of changing sowing date on grain yield}

To determine the optimum date for sowing, simulation has been done using AquaCrop from 11th January to 22nd March for every time slot for both the scenarios. Among the various sowing dates evaluated for A2 scenario, 1st February is found optimum for the present scenario and 2012-40 which can increase the yield upto $2.7 \%$ and $5 \%$ respectively whereas, 25 th and 18th January are suitable for 2041-70 and 207199 which probably can increase the yield upto $13.4 \%$ and $22.5 \%$ respectively as compared to the yield by general sowing date for the present situation which is 15 th February. Increased temperature during the tasselling period affects the production of the kernel which may be the probable reason for the increase. Hence, with planting before the present schedule of planting 


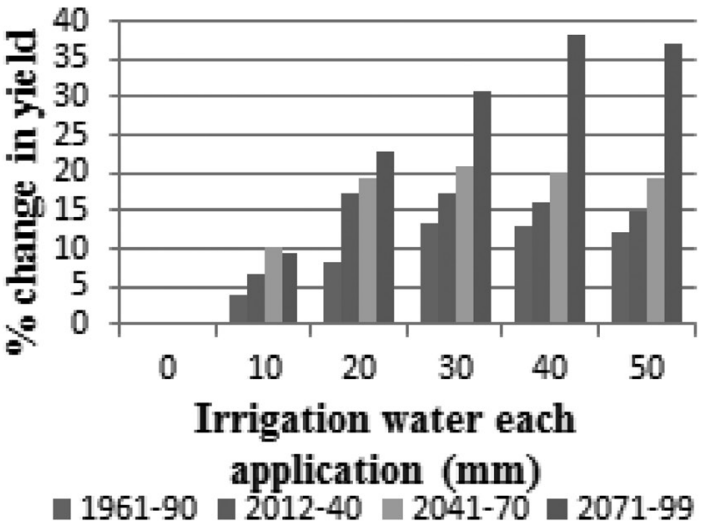

(a)

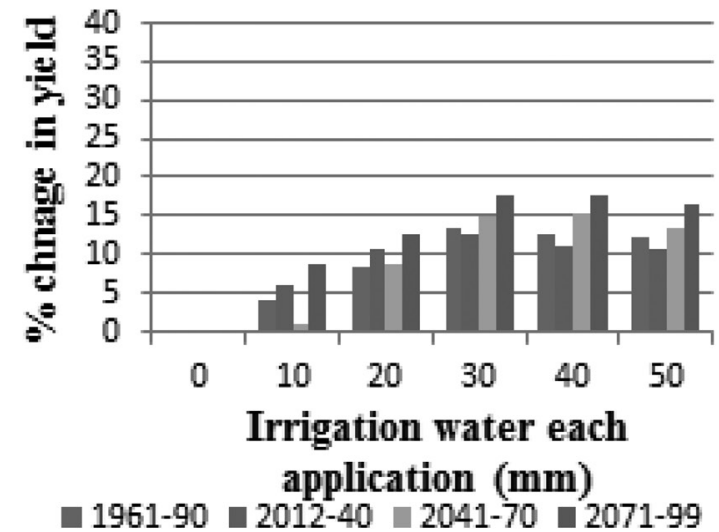

(b)

Figure 7 : Change in yield (\%) with supplement irrigation for the cultivar NLD - White for (a) A2 emission scenario and (b) B2 scenario.

date the yield is increased. In case of B2 scenario, the optimum date for getting maximum yield is 1st February for 2012-40, however the optimum day for the time window 2041-70 and 2071-99 are 25th January and 18th January respectively which can increase the yield upto $11.4 \%$ and $11 \%$ respectively. Figure 6 (a) and (b) shows the change in yield by varying the sowing dates for A2 and B2 scenarios respectively.

\subsection{Effect of supplementary irrigation on grain yield}

Figure 7 (a) and (b) shows the percent change in the yield under supplementary irrigation which was in order of $0,10,20,30,40$ and $50 \mathrm{~mm}$ for 4 applications as compared to rainfed agriculture under A2 and B2 emission scenarios. The yield is simulated using AquaCrop for the three time windows. The analysis is also done to evaluate the amount of irrigation suitable for the present condition. The simulation reveals that for the present climate condition, it is necessary to opt for irrigated agriculture by which the yield can be increased upto $13.5 \%$ for an optimum irriga- tion of $30 \mathrm{~mm}$ per application i.e. a total of 120 $\mathrm{mm}$.

For A2 scenario, the optimized amount of irrigation for 2012-40 is $20 \mathrm{~mm}$ per application which probably can increase yield to $17.1 \%$ whereas for 2041-70 the optimum irrigation is $80 \mathrm{~mm}$ with 4 applications with increment in yield of $20.7 \%$. However, in case of 2071-99 the optimum irrigation water is $160 \mathrm{~mm}$ which probably can boost the yield upto $38 \%$ as compared to rainfed agriculture. Since the application of water in the last time slice increase the yield to a high percentage it implies that the precipitation in this slice is relatively very low in the growing season then the amount required by the plant.

For B2 scenario, the yield for 2012-40 increases to $12.6 \%$ with irrigation of $120 \mathrm{~mm}$ (4 applications) and for 2041-70 and 2071-99 the modeled increment is $15.1 \%$ and $17.6 \%$ respectively with the same amount of irrigation. This implies that the cumulative precipitation is lacking by $120 \mathrm{~mm}$ for all the time slices during the growing period if other climate parameters are not considered. 


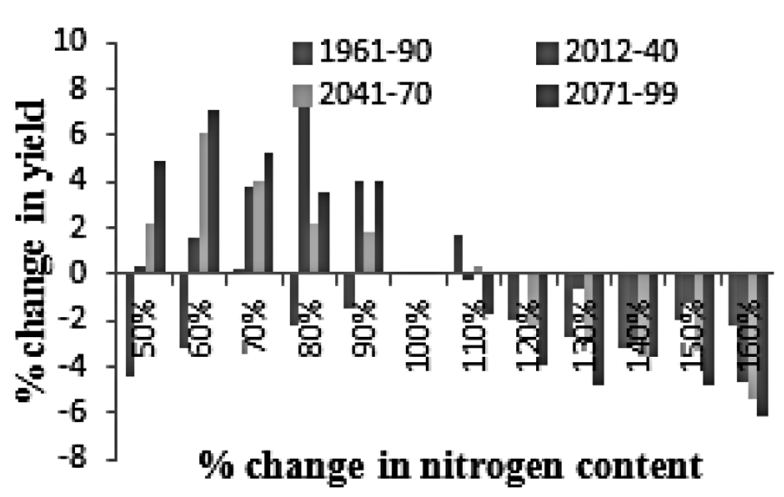

(a)

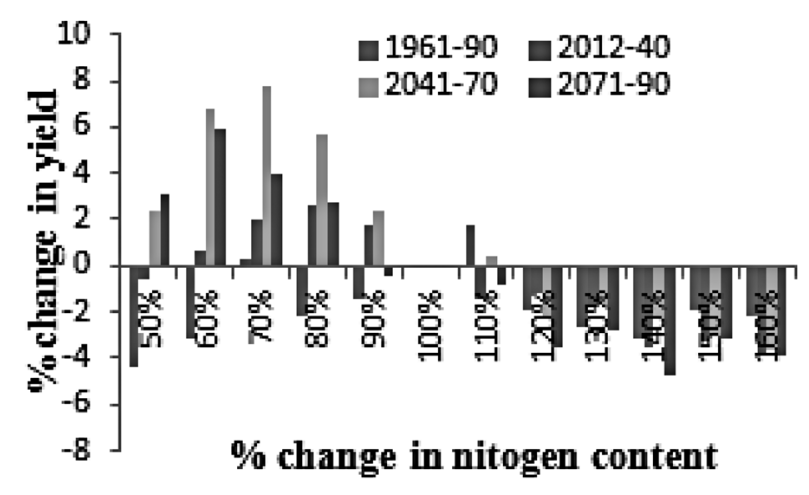

(b)

Figure 8 : Percent change in the yield of maize with different application rate of FYM under (a) A2 scenario and (b) B2 scenario.

\subsection{Effect of changed FYM application on grain yield}

Model simulation suggests, for A2 scenario under present climate the optimum amount of FYM to be input is $110 \%$ which can improve the yield upto $1.72 \%$ which is quite less as per as input of FYM is considered. Hence, $100 \%$ of FYM is ideal in the present condition. For $2012-40$, the optimum input is $80 \%$ with an increase of $7.5 \%$ yield as compared to the present amount of FYM input. However, for 2041-70 and 2071-99 the optimum input is $60 \%$ of the present input which probably can increase the yield upto 6.2 and $7.1 \%$ respectively. For B2 scenario, at 2102-40 the optimum application rate is $80 \%$ with increment in yield of $2.6 \%$ and for $2041-7070 \%$ of present FYM application can increase the yield upto $7.7 \%$. However for 2071-99 optimum application rate is $60 \%$ with increase in yield of 5.9\%. Figure 8 (a) and (b) illustrates the effect of different rates of FYM application on yield (\%) for A2 and B2 scenario.

\section{CONCLUSIONS}

The present study has been conducted to assess the impacts of climate change and evalu- ation of agro-adaptation measures for maize yield in East Sikkim, India. The study is based on secondary data on weather, crop management and soil characteristics. The future climate data used for this research has been obtained from the GCM HadCM3. Transferring coarse resolution climate data to station level was done by statistical model SDSM. Maximum and minimum temperature is expected to increase in the future for the two scenarios. Precipitation is expected to decrease under the two scenarios which accumulated with temperature will have adverse affect on the maize yield. Suitable adaptive measures were evaluated to counter the negative impacts of climate change on maize productivity in the study area to ensure food security.

\section{ACKNOWLEDGEMENTS}

The authors acknowledge Indian Meteorological Department, India for providing the meteorological data and Indian Council of Agricultural Research, Sikkim office, India for availing the field experimental data on Maize for the study. 


\section{REFERENCES}

Alcamo, J., Dronin, N., Endejan, M., Golubev, G., \& Kirilenko, A., 2007. A new assessment of climate change impacts on food production shortfalls and water availability in Russia. Glob. Environ. Change 17, 429-444.

Babel, M.S., Agarwal, A., Swain, D.K. \& Herath, S., 2011. Evaluation of climate change impacts and adaptation measures for rice cultivation in Northeast Thailand. Clim. Res. 46, 137-146.

Bardosy, A. \& Plate, E.J., 1992. Space-time model for daily rainfall using atmospheric circulation patterns, Wat. Resources Res. 28(5), 1247-1259.

Carter, T.R. \& Parry, M.F., 1994. Implications from environmental manipulation experiments for arctic plant biodiversity changes. In: Arctic and Alpine Biodiversity: Patterns, Causes and Ecosystem Consequences [Chapin, F.S. and C.Korner (eds.)]. Springer Verlag, Stuttgart, Germany.

Debnath, P., Deb, P., Sen, D., Pattannaik, S.K., Sah, D. \& Ghosh, S.K., 2012. Physicochemical properties and its relationship with water holding capacity of cultivated soils along altitudinal gradient in Sikkim. Intl. J. Agric. Environ. Biotech. 5(1), 99102.

Gao, S., Ding, Y. \& Zhao, Z., 1993. The possible greenhouse impact of atmospheric $\mathrm{CO} 2$ content increasing on the agricultural production in future China. Scientia Atmospherica Sinica 17, 584-591.

Horie, T., 2005. Climate change and food security with special attention to rice. In: Proc. Glob. Environ. Action (GEA) Conf for sustainable future '05. Tokyo.
Hsiao, T.C., Heng, T.K., Steduto, P., RojasLara, B., Raes, D. \& Fereres, E., 2009. AquaCrop - The FAO crop model to simulate yield response to water: III. Parameterization and testing for maize. Agron. J. 101, 448-459.

IPCC, 2007. Climate change: impacts, adaptation and vulnerability. Contribution of Working Group II to the 4th assessment report of the intergovernmental panel on climate change. Cambridge University Press, Cambridge.

Kimball, B.A., 1983. Carbon dioxide and agricultural yield: an assemblage and analysis of 430 prior observations. Agron. J. 75, 700-703.

Long, S.P., 1991. Modification of the response of photosynthetic productivity to rising temperature by atmospheric $\mathrm{CO} 2$ concentrations: has its importance been underestimated? Plant Cell Environ. 14(8), 729-739.

Li, Y., Jiang, J., Long, G. \& Cheng, Y., 1993. The influence of climate warming on rice production in China. In: The Impact of Climate Variations on Agriculture and Its Strategic Counter-measure. Beijing University Press, Beijing, China, pp. 54-130.

Ma, S. \& Liang, H., 1990. The estimating method of thermal resources and the arrangement of crop variety in the Changbai mountainous region. Mountain Res. 8 , 161-166.

Maybeck, M., Green, P. \& V $\square \mathrm{r} \square$ smarty, C., 2001. A new typology for mountains and other relief classes: An application to global continental water resources and population distribution. Mount. Res. Dev. 21, 34-45. 
Meza, F.J., Silva, D. \& Vigil, H., 2008. Climate change impacts on irrigated maize in Mediterranean climates: Evaluation of double cropping as an emerging adaptation alternative. Agricultural Systems 98, 21-30.

Molua, E.L., 2009. An empirical assessment of the impact of climate change on smallholder agriculture in Cameroon. Glob. Planet Change 67, 205-208.

Nelson, G.C., Rosegrant, M.W., Koo, J., Robertson, R., Sulser, T., Zhu, T., Ringler, C., Msangi, S., Palazzo, A., Batka, M., Magalhas, M., Valmonte-Santos, R., Ewing, M. \& Lee, D., 2009. Climate change: impact on agriculture and costs of adaptation. International Food Policy Research Institute, Washington, DC.

Raes, D., Steduto, P., Hsiao, T.C. \& Fereres, E., 2009. AquaCrop - The FAO crop model to simulate yield response to water: II. Main algorithms and software description. Agron. J. 101, 438-447.

Reilly, J., Tubiello, F., McCarl, B., Abler, D., Darwin, R., Fuglie, K., Hollinger, S., Izaurralde, C., Jagtap, S., Jones, J., Mearns, L., Ojima, D., Pail, E., Paustian, K., Riha, S., Rosenberg, N. \& Rosenberg, C., 2003. US agriculture and climate change: new results. Climatic Change 57(1), 43-69.

Rivington, M., Matthews, K.B., Buchan, K., Miller, D.G., Bellocchi, G. \& Russel, G. 2013. Climate change impacts and adaptation scope for agriculture indicated by agro-meteorological metrics. Agric. Systems. 114, 15-31.

Rui-li, L.I. \& Geng, S., 2013. Impacts of Climate Change on Agriculture and Adapta- tive Strategies in China. J. of Integrative Agriculture. 12(8), 1402-1408.

Russo, J. \& Zack, J., 1997. Downscaling GCM output with a mesoscale model. J. Environ. Manage. 49, 19-29.

Steduto, P., Hsiao, T.C., Raes, D. \& Fereres, E., 2009. AquaCrop - The FAO model to simulate yield response to water: I. concepts and underlying principles. Agron. J. 101, 426-437.

Supit, I., ven Diepen, C.A., de Wit, A.J.W., Wolf, J., Kabat, P., Baruth, B. \& Ludwig, F. 2012. Assessing climate changes effects on European crop yields using Crop Growth Monitoring System and a weather generator. Agric. and Forest Meteor. 164, 96-111.

Tao, F. \& Zhao, Z., 2010. Adaptation of maize production to climate change in North China Plain: Quantify the relative contributions of adaptation options. European J. of Agron. 33, 103-116.

Tao, F., Yokozawa, M., Xu, Y., Hayashi, Y., Zhang, Z., 2006. Climate changes and trends in phenology and yields of field crops in China, 1981-2000. Agric. Forest Meteorol. 138, 82-92.

Wang, J., Huang, Z., Zhong, T. \& Chen, Z. 2013. Climate change impacts and adaptation for saline agriculture in north Jiangsu Provience, China. Environ. Science \& Policy. 25, 83-93.

Wilby, R.L., Dawson, C.W. \& Barrow, E.M., 2002. SDSM - a decision support tool for the assessment of regional of regional climate change impacts. Environ. Model. Softw. 17(2), 147-159. 